\title{
FGFR3 gene mutation plus GRB10 gene duplication in a patient with achondroplasia plus growth delay with prenatal onset
}

\author{
Haiming Yuan ${ }^{1,2 \dagger}$, Linhuan Huang ${ }^{3+}$, Xizi Hu ${ }^{4}$, Qian Li ${ }^{5}$, Xiaofang Sun ${ }^{6}$, Yingjun Xie ${ }^{6 *}$, Shu Kong ${ }^{6}$ \\ and Xiaoman Wang ${ }^{6}$
}

\begin{abstract}
Background: Achondroplasia is a well-defined and common bone dysplasia. Genotype- and phenotype-level correlations have been found between the clinical symptoms of achondroplasia and achondroplasia-specific FGFR3 mutations.

Result: A 2-year-old boy with clinical features consistent with achondroplasia and Silver-Russell syndrome-like symptoms was found to carry a mutation in the fibroblast growth factor receptor-3 (FGFR3) gene at c.1138G > A (p.Gly380Arg) and a de novo $574 \mathrm{~kb}$ duplication at chromosome 7p12.1 that involved the entire growth-factor receptor bound protein 10 (GRB10) gene. Using quantitative real-time PCR analysis, GRB10 was over-expressed, and, using enzyme-linked immunosorbent assays for IGF1 and IGF-binding protein-3 (IGFBP3), we found that IGF1 and IGFBP3 were low-expressed in this patient.
\end{abstract}

Conclusions: We demonstrate that a combination of uncommon, rare and exceptional molecular defects related to the molecular bases of particular birth defects can be analyzed and diagnosed to potentially explain the observed variability in the combination of molecular defects.

Keywords: Achondroplasia, GRB10, Duplication, Over-expression, Silver-Russell syndrome

\section{Background}

Achondroplasia (ACH, OMIM \#100800) is the most common non-lethal skeletal dysplasia. It is an autosomaldominant disorder with an incidence of approximately 515 per 100,000 live births. Mutations in FGFR3 at c.1138 G > A (p.Gly380Arg) are known to cause ACH, with $97 \%$ of cases involving this mutation [8, 22]. Gain-offunction mutations in FGFR3 have been shown to cause both chondrodysplasias and craniosynostoses and to result in impaired endochondral ossification [3].

\footnotetext{
* Correspondence: fairyfareyj@sina.com

Haiming Yuan and Linhuan Huang are co-first author.

${ }^{\dagger}$ Equal contributors

${ }^{6}$ Key Laboratory for Major Obstetric Diseases of Guangdong Province, Key Laboratory of Reproduction and Genetics of Guangdong Higher Education Institutes, The Third Affiliated Hospital of Guangzhou Medical University, 63 Duobao Rd., Guangzhou 510150, People's Republic of China

Full list of author information is available at the end of the article
}

While patients with maternal uniparental disomy of chromosome 7 (mUPD7) that involves GRB10 are consistently diagnosed with Silver-Russell syndrome (SRS, OMIM \#180860) [4, 7]. SRS is a rare congenital developmental disorder that is characterized by severe intrauterine and postnatal growth restriction, a triangular-shaped face, and congenital malformations that include relative macrocephaly, hemihypotrophy, and fifth-finger clinodactyly [24]. However, there is no conclusive evidence regarding the pathogenic mechanism by which GRB10 (i.e., imprinting vs. dosage) contributes to the etiology of SRS.

Currently, only $6 S R S$ patients have been shown to carry GRB10 duplications. In 1999, Joyce et al. described a mother and daughter who were both diagnosed with SRS and who both carried a duplication at 7p12.1-p13, which includes GRB10 and IGFBP1. The mother carried a paternally derived duplication, and the daughter 
carried a maternally derived duplication [13]. The next year, Monk et al. reported a de novo maternal duplication of 7p11.2-p13 in a patient with SRS [17]. Subsequently, two more individuals (A.C. and H.C.) with SRS were reported to possess larger duplications at this same locus: A.C. carried a maternally derived duplication, but the parent of origin for H.C.'s duplication was not known [16]. Recently, Eggermann reported a boy who displayed heterogeneous growth patterns and carried a de novo paternally derived duplication at $7 \mathrm{p} 12.2$ [6]. A few additional cases have been reported to the Decipher and ISCA databases (Fig. 4a, Table 1). All of these reported duplications involved the GRB10 gene, which is regarded as the most promising candidate gene at this locus (Fig. 2). Because all of these duplications were large (except Decipher case 289205, which had a partial GRB10 gene duplication), it is possible that neighboring genes, particularly genes such as IGFBP1 and IGFBP3, could contribute to SRS, and the involvement of these genes has not been completely ruled out in these cases. As a result, the correlations between SRS genotypes and phenotypes that are associated with duplications of GRB10 remain incompletely understood.

Here, we report a patient who displayed prenatal onset growth delay and $\mathrm{ACH}$ and carried a small de novo duplication at $7 \mathrm{p} 12.1$ that involved the GRB10 gene in addition to a heterozygous point mutation at FGFR3. We detected the smallest known duplication in a patient who displayed one of the typical clinical features of SRS. This duplication was restricted to the GRB10 gene at 7p12.1. This case provides direct evidence showing that a GRB10 duplication is sufficient to cause the prenatal onset growth delay phenotype in SRS and the combination of these two molecular defects may explain the socalled variable expressivity dominant traits.

\section{Methods}

\section{Clinical report}

A 2-year-old Chinese boy was referred and admitted to our hospital because of congenital malformations and development delay over the previous month. He presented with a characteristically small triangular face with a prominent forehead and low nasal bridge, micrognathia and downturned corners of the mouth, and sparse hair (Fig. 1). He could not walk but could sit with support, and his language development was significantly delayed. He had been previously diagnosed with global developmental delay (date not provided), and he exhibited short limbs and relative macrocephaly without compensatory growth at 6 months of age.

A physical examination resulted in the following findings: height, $66 \mathrm{~cm} \mathrm{(<1} \mathrm{rd} \mathrm{percentile);} \mathrm{weight,} 7.5 \mathrm{~kg}$ ( $<1 \mathrm{rd}$ percentile); head circumference, $52 \mathrm{~cm}$ ( $<3$ rd percentile); and BMI, $17.2 \mathrm{~kg} / \mathrm{m}^{2}$, indicating a persistent failure to thrive. In addition, the patient had trident hands and fifth finger clinodactyly. An X-ray of the hand showed stubby fingers, metaphyseal enlargement, bilateral slight curvature of the radius and ulna, and delayed bone age. A spine X-ray showed mild scoliosis and kyphosis at the thoracic and lumbar region (Fig. 2), which indicated achondroplasia. A cerebral MRI showed a hypoplastic corpus callosum, enlargement of the lateral ventricles and hydrocephalus (Fig. 3). In addition, he exhibited muscular hypotonia and sleep-related symptoms (e.g., snoring, mouth breathing, observed apneas, and excessive sweating). An ophthalmological examination and neurometabolic investigation were normal. Based on the above clinical phenotype, a diagnosis of SRS-like symptoms and achondroplasia was suspected.

The patient was the fourth child of healthy unrelated parents with a negative family history. His siblings were all healthy. Fetal short limbs were noticed on the ultrasound examination at 8 months of pregnancy, indicating intrauterine growth restriction (date not provided). He was born by vaginal delivery at 38 weeks of gestation after an uneventful pregnancy. His birth weight was $1900 \mathrm{~g}(<1$ st percentile), his length was $43 \mathrm{~cm}(<1$ st percentile) and his head circumference was $34 \mathrm{~cm}$. His Apgar scores were all 9 s. Feeding difficulty was noted during the first two months after birth.

\section{Karyotyping and chromosomal microarray analysis}

A standard chromosome analysis at 550-band resolution was performed using cultured peripheral blood from the patient according to standard procedures.

A chromosomal microarray analysis (CMA) of the patient and his parents was performed using an Affymetrix Cytoscan HD Array (Affymetrix, Santa Clara, CA, USA). Genomic DNA was extracted from peripheral blood using a commercial kit (Qiagen). The labeling and hybridization procedures were performed according to the manufacturer's instructions. The raw CMA data were analyzed using Affymetrix Chromosome Analysis Suite software. The microarray data for the family trio were then processed using the standard protocols provided by the manufacturer to perform a basic analysis using Chromosome Analysis Suite software (NetAffx 33.1, Affymetrix, USA).

\section{Confirmation of GRB10 duplication}

The GRB10 copy number was further confirmed using quantitative real-time PCR analysis. The primer sequences that were used and their descriptions are included in Additional file 1: Table S1.

\section{GRB10 expression level}

GRB10 expression levels were detected in blood samples using quantitative real-time PCR analysis. Total RNA was extracted from whole blood, and reverse 
Table 1 Review genomic and clinical information on patients with duplication involving GRB10

\begin{tabular}{|c|c|c|c|c|c|c|c|c|}
\hline Patient/source & Our patient & $\begin{array}{l}\text { Patients TB/LB from } \\
\text { Joyce et al. [13] }\end{array}$ & $\begin{array}{l}\text { Patient DP from Monk } \\
\text { et al. [17] }\end{array}$ & $\begin{array}{l}\text { Patients HC/AC from } \\
\text { Monk et al. [16] }\end{array}$ & $\begin{array}{l}\text { Patient from Eggermann } \\
\text { et al. [6] (decipher 285981) }\end{array}$ & $\begin{array}{l}\text { Decipher } \\
289205\end{array}$ & $\begin{array}{l}\text { Decipher } \\
276327\end{array}$ & ISCA nssv579045 \\
\hline $\begin{array}{l}\text { Genomic } \\
\text { location (hg19) }\end{array}$ & $\begin{array}{l}\text { chr7:50654827- } \\
5122921\end{array}$ & $\begin{array}{l}\text { chr7:42029531- } \\
51138357 \\
\text { (D7S691-D7S242) }\end{array}$ & $\begin{array}{l}\text { chr7:40742989-50861159 } \\
\text { (D7S1769-GRB10) }\end{array}$ & $\begin{array}{l}\text { chr7:41392336-54000000 } \\
\text { (RP5-953B5-7p11.2) }\end{array}$ & chr7:47034222-52175639 & $\begin{array}{l}\text { chr7:50713413- } \\
50982532\end{array}$ & $\begin{array}{l}\text { chr7:43566637- } \\
51282735\end{array}$ & chr7:33367924-61831899 \\
\hline $\begin{array}{l}\text { Duplication } \\
\text { size }\end{array}$ & $574 \mathrm{~Kb}$ & $\sim 10 \mathrm{cM}$ & $\sim 10 \mathrm{cM}$ & $>10 \mathrm{cM}$ & $5.1 \mathrm{Mb}$ & $270 \mathrm{~Kb}$ & $7.72 \mathrm{Mb}$ & $28.5 \mathrm{Mb}$ \\
\hline \multirow{2}{*}{$\begin{array}{l}\text { Inheritance/ } \\
\text { orign }\end{array}$} & \multirow{2}{*}{$\begin{array}{l}\text { de novo/ } \\
\text { maternal }\end{array}$} & LB: maternal & \multirow[t]{2}{*}{ de novo/maternal } & AC: maternal & \multirow[t]{2}{*}{ de novo/paternal } & \multirow{2}{*}{$\begin{array}{l}\text { inherited/ } \\
\text { paternal }\end{array}$} & \multirow{2}{*}{$\begin{array}{l}\text { de novo/ } \\
\text { unknown }\end{array}$} & \multirow[t]{2}{*}{ unknown } \\
\hline & & TB: paternal & & HC: unknown & & & & \\
\hline Phenotype & SRS & SRS & SRS & SRS-like & $\begin{array}{l}\text { overgrowth, DD, } \\
\text { microcephaly, seizure }\end{array}$ & $\begin{array}{l}\text { hypotonia, } \\
\text { GDD }\end{array}$ & $\begin{array}{l}\text { muscular } \\
\text { hypotonia }\end{array}$ & $\begin{array}{l}\mathrm{FTT}, \mathrm{GDD} \text {, large eyes, } \\
\text { microcephaly, short stature, } \\
\text { triangular face }\end{array}$ \\
\hline $\begin{array}{l}\text { Detection } \\
\text { method }\end{array}$ & array & karyotype/FISH & karyotype/FISH & karyotype/FISH & array & array & array & array \\
\hline $\begin{array}{l}\text { Genes involved } \\
\text { (Refseq) }\end{array}$ & $\begin{array}{l}\text { GRB10 and part } \\
\text { of COBL }\end{array}$ & $>50$ genes & $>50$ genes & $>50$ genes & $>20$ genes & Part of GRB10 & $>40$ genes & $>180$ genes \\
\hline
\end{tabular}

Abbreviation: FISH fluorescence in situ hybridization, $D D$ developmental delay, GDD Global developmental delay, FTT: failure to thrive 

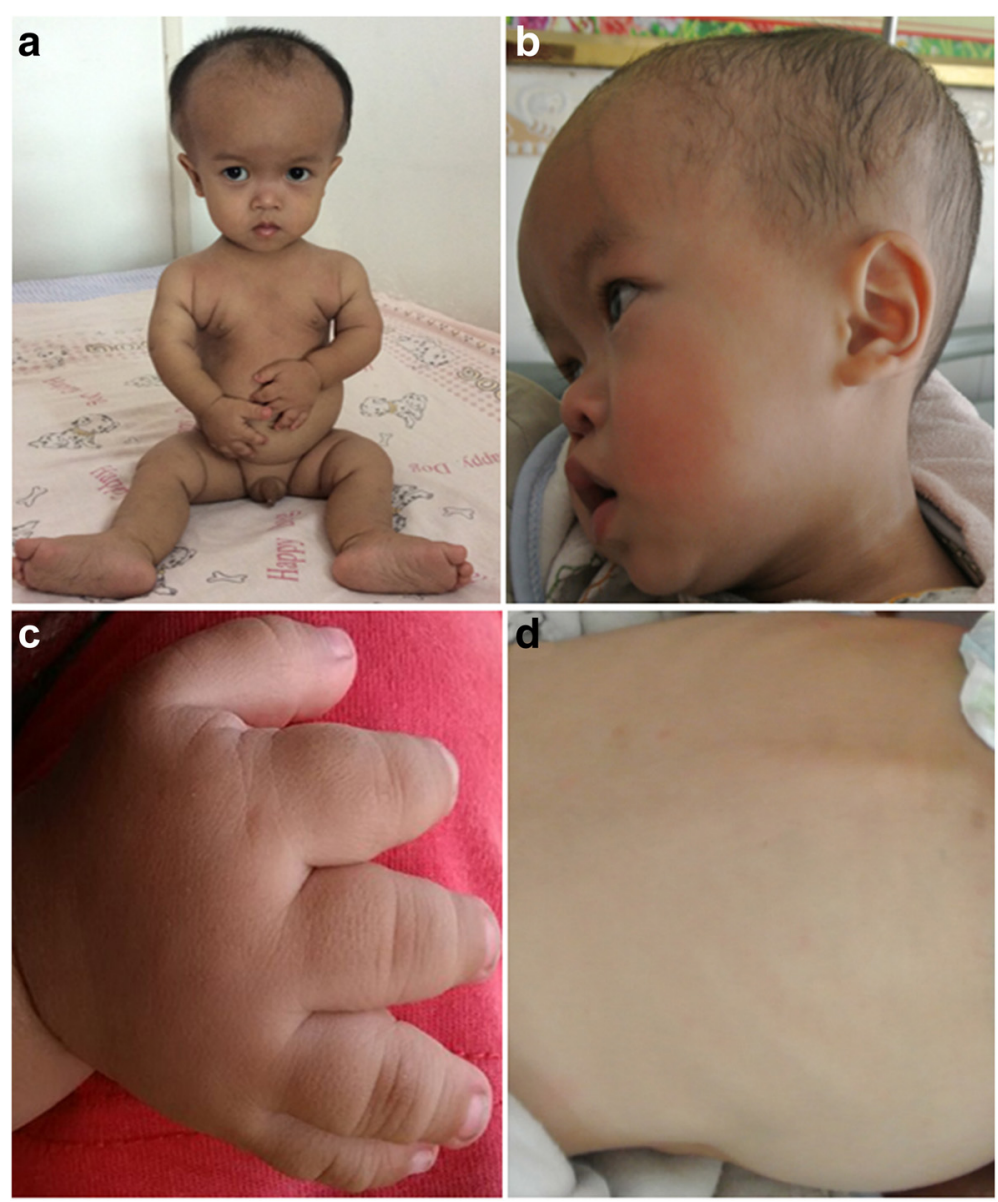

Fig. 1 Clinical features of the proband at 2 years of age. a Note the prominent forehead, triangular face, downward-slanting mouth and micrognathia. The proband also presented with very short limbs and body asymmetry, $\mathbf{b}$ a low nasal bridge, and $\mathbf{c}$ trident hands and fifth finger clinodactyly, $\mathbf{d}$ scoliosis

transcription was performed using a commercial kit (Promega, USA). A blood sample from the proband's mother was used as the control. The primer sequences that were used and their descriptions are included in Additional file 1: Table S2.

\section{Measurement of IGF1 and IGFBP3}

We measured the levels of IGFI and IGF binding protein-3 (IGFBP3) in the patient's serum using enzymelinked immunosorbent assay (ELISA) kits (Diagnostic Systems Laboratories, Webster, TX, USA) according to the manufacturer's instructions.

\section{Sequencing of the fibroblast growth factor receptor-3 gene (FGFR3)}

DNA samples were tested for common disease-associated mutations in FGFR3 (achondroplasia and hypochondroplasia: p.Gly380Arg and p.Asn540Lys, respectively; thanatophoric dysplasia type I: p.Arg248Cys, p.Tyr373Cys, p.Ser249Cys, and p.X807; and thanatophoric dysplasia type II: p.Lys650Glu) using Sanger sequencing. The primer sequences are shown in Additional file 1: Table S3 (reference sequence for the FGFR3 gene: NM_000142.4). Sanger sequencing was performed according to the manufacturer's instructions using a Big Dye Terminator Cycle Sequencing Kit (version 3.1) and analyzed using an ABI Prism 3130xl Genetic DNA analyzer.

\section{Results}

Karyotyping analysis of the patient revealed a normal 46, $\mathrm{XY}$ karyotype. CMA revealed a $574 \mathrm{~kb}$ duplication at 7p12.1 (arr[hg19] 7p12.1(50,654,827- 51,229,221) × 3dn) (Fig. 4). This duplication was not detected in either the patient's parents or siblings, indicating that it was a de novo duplication. We used Chromosome Analysis Suite software (NetAffx 33.1, Affymetrix, USA) to analyze the family trio SNP-array data, and we found that the duplication originated from the mother. The duplication was further confirmed using RT-PCR analysis. The GRB10 expression level in the patient's blood was three-fold higher than the level in his mother's blood (Fig. 5a). The levels of IGF1 and IGFBP3 in the patient were $<25.0 \mathrm{ng} / \mathrm{ml}$ 


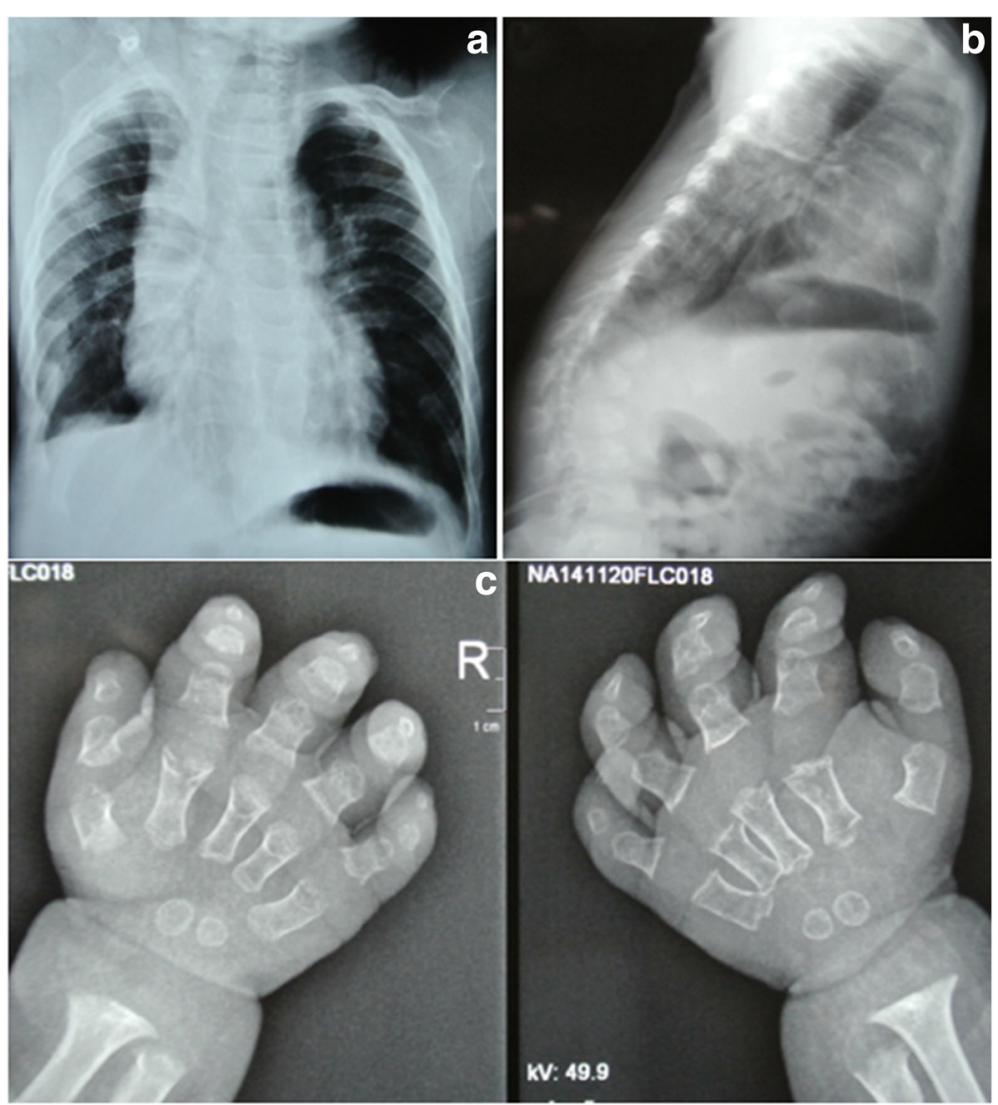

Fig. 2 Spine X-ray images showed mild kyphosis (a) and scoliosis (b) at the thoracic and lumbar region. Bone age is delayed (c)

and $1.78 \mathrm{ng} / \mathrm{ml}$, respectively, which was far below normal levels. Sequencing of the FGFR3 gene identified a FGFR3 c.1138 G > A (p.Gly380Arg) mutation (Fig. 5b).

\section{Discussion}

The patient exhibited features such as scoliosis and a trident configuration of the hands all of which can be explained by a mutations in FGFR3 at c.1138 G>
A(p.Gly380Arg). However, the speech delay, hypotonia and small triangular face phenotypes were not commonly reported in previous cases of ACH (Table 2) [9, 12]. A hypoplastic corpus callosum and hydrocephalus could potentially be CNS manifestations of non-treated/severe achondroplasia. In addition, the observation of a global developmental delay could not be definitively separated from the consequences of the identified FGFR3 mutation.

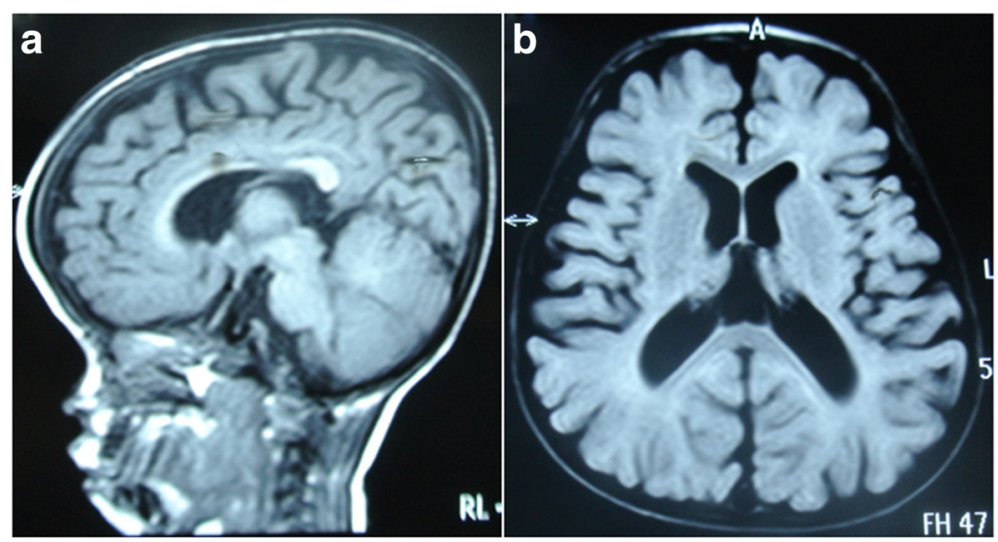

Fig. 3 Brain MRI images showed a hypoplastic corpus callosum, enlargement of the lateral ventricles and hydrocephalus (a and $\mathbf{b}$ ) 


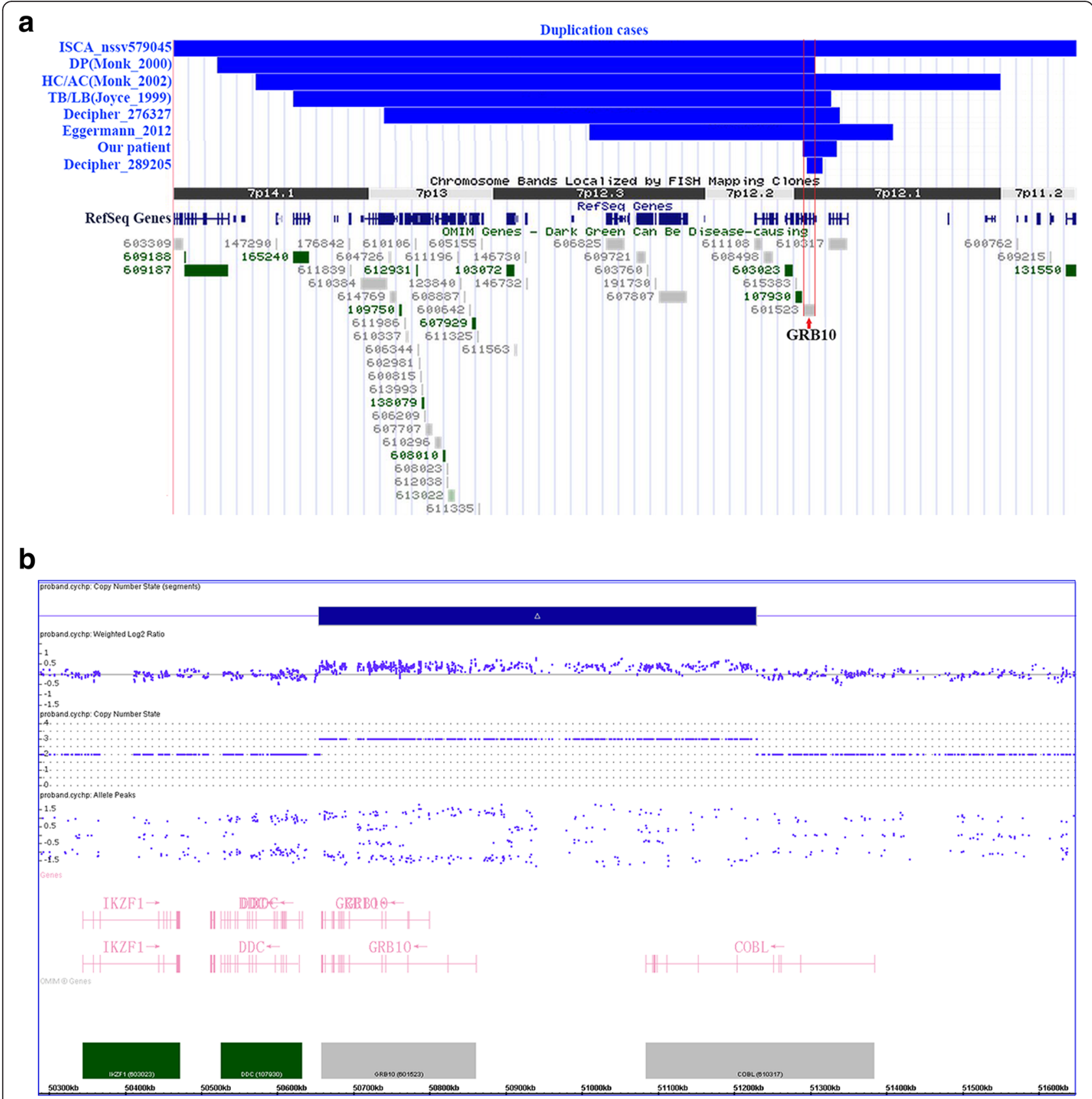

Fig. 4 Overview of previously described cases shown to have genomic imbalances at 7p12.1 that involved GRB10. (Blue: duplications). Red vertical lines demarcate the genomic interval of the GRB10 gene (a). Scatter plot of a Cytoscan HD array at 7p12.1 showing a duplication interval involving the whole GRB10 gene and part of the COBL gene (b)

Finally, at birth, patients with achondroplasia present with a relatively short stature that does not affect weight, whereas this patient had a low weight at birth. In addition, no overt body asymmetry was reported in this patient. Accordingly, the one unique feature of this patient that can be directly linked to a GRB10 duplication is the prenatal onset growth delay.

In our patient, we detected a three-fold increase in GRB1O expression. GRB10 is an imprinted gene on 7p12.1. Because it is a key genetic component of developmental programming, recent studies have also suggested that placental GRB1O plays a role in regulating fetoplacental growth and that it is thereby implicated in the pathophysiology of fetal growth restriction in the context of fetal gender $[2,26]$. Studies have consistently supported the notion that increases in gene dosage are the main contributors to the over-production of the GRB10 gene product. The GRB10 gene encodes an 


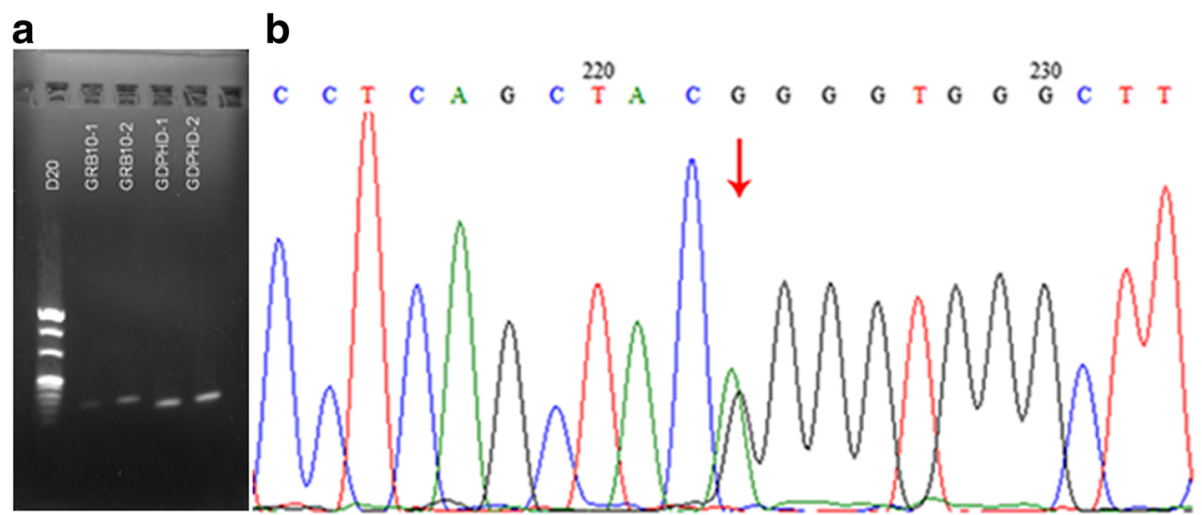

Fig. 5 a GRB10 expression levels were analyzed in blood samples using RT-PCR. b DNA sequences corresponding to the patient's FGFR genes. A FGFR3 c.1138 G > A (p.Gly380Arg) mutation was found

adaptor protein that interacts with IGF1 and insulin receptors to negatively regulate the IGF1 growth cascade $[5,18]$. A previous study reported that endogenous GRB10 expression was increased in the hippocampus of rats with diabetic encephalopathy and that this increase might result in damaged nerve functions and cognitive impairments. In addition, the insulin/IGF1 signaling pathways have been implicated in dysregulated synaptic maturation and may play key roles in brain aging and dementia as well as learning and cognitive functions in rodent models [14, 19]. In the present study, the IGF1 and IGFBP3 levels in the patient were far below normal levels, consistent with a model in which the duplication of GRB10 directly inhibits the phosphorylation of the $I G F 1 R$ substrate and reduces the level of Grb10 expression to below normal limits, which may result in nervous system impairments such as growth delays and intellectual disabilities (ID) [23]. These findings suggest

Table 2 Comparison of clinical abnormalities with Achondroplasia (ACH) and Silver-Russell syndrome (SRS)

\begin{tabular}{|c|c|c|c|}
\hline Clinical abnormalities & Achondroplasia (ACH) & Silver-Russell syndrome (SRS) & Our patient \\
\hline Prenatal IUGR & - & + & + \\
\hline \multicolumn{4}{|l|}{ Special face } \\
\hline macrocephaly & - & + & + \\
\hline broad foreheads & + & - & + \\
\hline pointed & - & + & + \\
\hline triangular shaped & - & + & + \\
\hline nose bridge collapse & + & - & + \\
\hline small chins & - & + & + \\
\hline \multicolumn{4}{|l|}{ Hand } \\
\hline a trident configuration of the hands & + & - & + \\
\hline fifth finger clinodactyly & - & + & + \\
\hline \multicolumn{4}{|l|}{ Body } \\
\hline asymmetry of limbs & - & + & + \\
\hline vertebrae & scoliosis & thoracic kyphosis & Scoliosis and thoracic kyphosis \\
\hline Hypotonia & - & + & + \\
\hline Developmental delay & - & + & + \\
\hline Delayed speech & - & + & + \\
\hline Intellectual disability & - & + & + \\
\hline Feeding difficulties in early childhood & - & + & + \\
\hline Snoring (coarse breath sounds) & + & - & + \\
\hline
\end{tabular}


that the duplication of GRB10 contributes to the prenatal onset growth delay phenotype that was observed in our patient and may also explain the ID features in SRS.

Previous studies of mice with uniparental disomy of Grb10 demonstrated that Grb10 is a typical imprinted gene and that it affects growth mainly via an imprinting mechanism [1, 20, 21, 25]. However, the imprinting behavior of human GRB10, which is located on chromosome 7, has been shown to be different from that of its mouse homolog [11]. Human GRB10 is biallelically expressed in most tissues, with the exception of the placental villus trophoblast and fetal brain tissues $[10,15]$. Because of the known complexity of the 7p12.1 imprinting regions and their interactions, interpretations of copy number variations in this region are complicated. The clinical outcomes in cases of micro-duplications are influenced by the size, breakpoint positions and parental inheritance of the imbalance and by the imprinting status of the affected genes.

Though, the duplication that was identified in our propositus could potentially have disrupted the genomic structure of the cordon-bleu WH2 repeat protein $(\mathrm{COBL})$ gene, which is specifically expressed in the node and its derivatives until organogenesis, we could not exclude the possibility that a disruption in $C O B L$ might have been involved in the patient's phenotype. In addition, there are no known correlations between mutations in FGFR3 and the duplication of GRB10.

\section{Conclusion}

The data related to the patient described in the present study at least suggest that mutations in FGFR3 cause $\mathrm{ACH}$ but do not influence the effects of the duplication of GRB10 on prenatal onset growth delay in SRS. The results of our study also suggest that phenotypes are rarely "simple" or directly related to specific gene defects and that combinations of uncommon, rare and exceptional molecular defects, which can be explored and used in diagnoses, may explain the so-called variability observed in the expression of dominant traits.

\section{Additional file}

Additional file 1: Supplemental Tables S1, S2 and S3. (XLSX 16 kb)

\footnotetext{
Abbreviation

CMA, chromosomal microarray analysis; COBL, cordon-bleu WH2 repeat protein; ELISA, enzyme-linked immunosorbent assay; FGFR3, fibroblast growth factor receptor-3; FGFR3, fibroblast growth factor receptor-3; GRB10, growth-factor receptor-bound protein 10; H19DMR, H19 promoter; HMGA2, high-mobility AT-hook 2; ICR1, Imprinted Center Region 1; ID, intellectual disability; IGFBP3, IGF binding protein-3; mUPD7, maternal uniparental disomy of chromosome 7; SRS, Silver-Russell syndrome
}

\section{Acknowledgments}

We would like to thank the family of the proband for their cooperation during this study.

\section{Funding}

This study was supported by the National Natural Science Foundation Committee of China (NSFC-81500974 to Xie Yingjun).

\section{Availability of data and materials \\ Affymetrix cytoscan HD (http://media.affymetrix.com/support/technical/ datasheets/cytoscan_hd_datasheet.pdf). \\ Chromosome Analysis Suite Software, Version 3.1 (http://www.affymetrix. $\mathrm{com} /$ support/technical/software_downloads.affx).}

\section{Authors' contributions}

$\mathrm{YH}$ and $\mathrm{HL}$ contributed equally to the manuscript. XY was responsible for the design of the project, data analysis, and manuscript write-up. XY also facilitated the panel with assistance from $\mathrm{YH}$ and $\mathrm{HL}$. YH and $\mathrm{XY}$ drafted the first versions of the manuscript. SX, KS and WX were the neurologists on the team, and they reviewed the relevant abstracts and articles and contributed to the final critical review of the write-up. HL, HX and LQ assisted in the literature review, performed the experiments, data entry, and data analysis phases of the project. All authors read and approved the final manuscript.

\section{Competing interests}

The authors declare that there are no potential conflicts of interest with respect to the research, authorship, and/or publication of this article.

\section{Consent for publication}

Consent to publish has been obtained from the guardians of all involved children.

\section{Ethics approval and consent to participate}

Ethical approval was obtained for this study from the Ethics Committee of the First Affiliated Hospital of Sun Yat-sen University (IRB 201301).

\section{Author details}

'Guangzhou KingMed Center for Clinical Laboratory Co., Ltd, Guangzhou 510330, Guangdong, China. ${ }^{2}$ KingMed School of Laboratory Medicine, Guangzhou Medical University, Guangzhou 510330, Guangdong, China. ${ }^{3}$ Fetal Medicine Centre, Department of Obstetrics and Gynaecology, The First Affiliated Hospital of Sun Yat Sen University, Guangzhou, Guangdong 510080, China. ${ }^{4}$ Fairmont Preparatory Academy, Anaheim, CA 92801, USA. ${ }^{5}$ Affymetrix Biotech Shanghai Ltd., Shanghai 200020, China. ${ }^{6}$ Key Laboratory for Major Obstetric Diseases of Guangdong Province, Key Laboratory of Reproduction and Genetics of Guangdong Higher Education Institutes, The Third Affiliated Hospital of Guangzhou Medical University, 63 Duobao Rd., Guangzhou 510150, People's Republic of China.

Received: 29 March 2016 Accepted: 9 June 2016

Published online: 02 July 2016

\section{References}

1. Charalambous M, Smith FM, Bennett WR, Crew TE, Mackenzie F, Ward A. Disruption of the imprinted Grb10 gene leads to disproportionate overgrowth by an lgf2-independent mechanism. Proc Natl Acad Sci U S A. 2003;100:8292-7.

2. Cowley M, Garfield AS, Madon-Simon M, Charalambous M, Clarkson RW, Smalley MJ, Kendrick H, Isles AR, Parry AJ, Carney S, Oakey RJ, Heisler LK, Moorwood K, Wolf JB, Ward A. Developmental programming mediated by complementary roles of imprinted Grb10 in mother and pup. PLoS Biol. 2014;12:e1001799.

3. Di Rocco F, Biosse Duplan M, Heuze Y, Kaci N, Komla-Ebri D, Munnich A Mugniery E, Benoist-Lasselin C, Legeai-Mallet L. FGFR3 mutation causes abnormal membranous ossification in achondroplasia. Hum Mol Genet. 2014;23:2914-25.

4. Dias RP, Bogdarina I, Cazier JB, Buchanan C, Donaldson MC, Johnston LB, Hokken-Koelega AC, Clark AJ. Multiple segmental uniparental disomy associated with abnormal DNA methylation of imprinted Loci in silverrussell syndrome. J Clin Endocrinol Metab. 2012;97:E2188-93. 
5. Dufresne AM, Smith RJ. The adapter protein GRB10 is an endogenous negative regulator of insulin-like growth factor signaling. Endocrinology. 2005;146:4399-409.

6. Eggermann T, Begemann M, Gogiel M, Palomares M, Vallespin E, Fernandez L, Cazorla R, Spengler S, Garcia-Minaur S. Heterogeneous growth patterns in carriers of chromosome 7p12.2 imbalances affecting GRB10. Am J Med Genet A. 2012;158A:2815-9.

7. Hannula-Jouppi K, Muurinen M, Lipsanen-Nyman M, Reinius LE, Ezer S, Greco D, Kere J. Differentially methylated regions in maternal and paternal uniparental disomy for chromosome 7. Epigenetics. 2014;9:351-65.

8. He X, Xie F, Ren ZR. Rapid detection of G1138A and G1138C mutations of the FGFR3 gene in patients with achondroplasia using high-resolution melting analysis. Genet Test Mol Biomarkers. 2012;16:297-301.

9. Hecht JT, Bodensteiner JB, Butler IJ. Neurologic manifestations of achondroplasia. Handb Clin Neurol. 2014;119:551-63.

10. Hikichi T, Kohda T, Kaneko-Ishino T, Ishino F. Imprinting regulation of the murine Meg1/Grb10 and human GRB10 genes; roles of brain-specific promoters and mouse-specific CTCF-binding sites. Nucleic Acids Res. 2003:31:1398-406.

11. Hitchins MP, Monk D, Bell GM, Ali Z, Preece MA, Stanier P, Moore GE. Maternal repression of the human GRB10 gene in the developing central nervous system; evaluation of the role for GRB10 in Silver-Russell syndrome. Eur J Hum Genet. 2001;9:82-90.

12. Ireland PJ, Donaghey S, McGill J, Zankl A, Ware RS, Pacey V, Ault J, Savarirayan R, Sillence D, Thompson E, Townshend S, Johnston LM. Development in children with achondroplasia: a prospective clinical cohort study. Dev Med Child Neurol. 2012;54:532-7.

13. Joyce CA, Sharp A, Walker JM, Bullman H, Temple IK. Duplication of 7p12.1p13, including GRB10 and IGFBP1, in a mother and daughter with features of Silver-Russell syndrome. Hum Genet. 1999;105:273-80.

14. Ma L, Wei Q, Deng H, Zhang Q, Li G, Tang N, Xie J, Chen Y. Growth factor receptor-bound protein 10-mediated negative regulation of the insulin-like growth factor-1 receptor-activated signalling pathway results in cognitive disorder in diabetic rats. J Neuroendocrinol. 2013;25:626-34.

15. Monk D, Arnaud P, Frost J, Hills FA, Stanier P, Feil R, Moore GE. Reciprocal imprinting of human GRB10 in placental trophoblast and brain: evolutionary conservation of reversed allelic expression. Hum Mol Genet. 2009:18:3066-74.

16. Monk D, Bentley L, Hitchins M, Myler RA, Clayton-Smith J, Ismail S, Price SM, Preece MA, Stanier P, Moore GE. Chromosome 7p disruptions in Silver Russell syndrome: delineating an imprinted candidate gene region. Hum Genet. 2002;111:376-87.

17. Monk D, Wakeling EL, Proud V, Hitchins M, Abu-Amero SN, Stanier P, Preece MA, Moore GE. Duplication of 7p11.2-p13, including GRB10, in Silver-Russell syndrome. Am J Hum Genet. 2000;66:36-46.

18. Morrione A. Grb10 adapter protein as regulator of insulin-like growth factor receptor signaling. J Cell Physiol. 2003;197:307-11.

19. Saenger S, Goeldner C, Frey JR, Ozmen L, Ostrowitzki S, Spooren W, Ballard TM, Prinssen E, Borroni E, Metzger F. PEGylation enhances the therapeutic potential for insulin-like growth factor I in central nervous system disorders. Growth Horm IGF Res. 2011;21:292-303.

20. Shiura H, Miyoshi N, Konishi A, Wakisaka-Saito N, Suzuki R, Muguruma K, Kohda T, Wakana S, Yokoyama M, Ishino F, Kaneko-Ishino T. Meg1/Grb10 overexpression causes postnatal growth retardation and insulin resistance via negative modulation of the IGF1R and IR cascades. Biochem Biophys Res Commun. 2005;329:909-16.

21. Shiura H, Nakamura K, Hikichi T, Hino T, Oda K, Suzuki-Migishima R, Kohda T, Kaneko-ishino T, Ishino F. Paternal deletion of Meg1/Grb10 DMR causes maternalization of the Meg1/Grb10 cluster in mouse proximal Chromosome 11 leading to severe pre- and postnatal growth retardation. Hum Mol Genet. 2009;18:1424-38.

22. Sobetzko D, Braga S, Rudeberg A, Superti-Furga A. Achondroplasia with the FGFR3 $1138 \mathrm{~g}->$ a (G380R) mutation in two sibs sharing a 4p haplotype derived from their unaffected father. J Med Genet. 2000;37:958-9.

23. Stein EG, Gustafson TA, Hubbard SR. The BPS domain of Grb10 inhibits the catalytic activity of the insulin and IGF1 receptors. FEBS Lett. 2001;493:106-11.

24. Varma SN, Varma BR. Clinical spectrum of Silver - Russell syndrome. Contemp Clin Dent. 2013;4:363-5.

25. Wang L, Balas B, Christ-Roberts CY, Kim RY, Ramos FJ, Kikani CK, Li C, Deng C, Reyna S, Musi N, Dong LQ, DeFronzo RA, Liu F. Peripheral disruption of the Grb10 gene enhances insulin signaling and sensitivity in vivo. Mol Cell Biol. 2007;27:6497-505.

26. Xue Y, Shankar S, Cornell K, Dai Z, Wang CE, Rudd MK, Coffee B. Paternal duplication of the $11 \mathrm{p} 15$ centromeric imprinting control region is associated with increased expression of CDKN1C in a child with RussellSilver syndrome. Am J Med Genet A. 2015;167A(12):3229-33.

\section{Submit your next manuscript to BioMed Central and we will help you at every step:}

- We accept pre-submission inquiries

- Our selector tool helps you to find the most relevant journal

- We provide round the clock customer support

- Convenient online submission

- Thorough peer review

- Inclusion in PubMed and all major indexing services

- Maximum visibility for your research

Submit your manuscript at www.biomedcentral.com/submit
Biomed Central 